\title{
Economic evaluation of energy-efficient engineering systems
}

\author{
Ivan A. Kapitonov* \\ Center of Tariff Regulation in the Energy Sector, Higher School of Tariff Regulation, Plekhanov Russian \\ University of Economics, Moscow, Russian Federation.
}

\begin{abstract}
The paper shows the aspects of introducing energy-efficient equipment for engineering systems within the context of productivity enhancement in general. The author as research relevance brings a thesis that each of production members reach after implementing possibility for increasing general effectiveness of business operation. The paper reveals the issues of factor and expert assessments for introducing innovations at the enterprise and economic evaluation of the place of energy-efficient technologies in the general medium of production enterprise modernization. The novelty of the study is an aspect that under conditions of energy products' cost increase and significant energy intensity of present-day production, the issue of energy conservation and choice of priorities of investment into the project of energy efficiency increase at enterprises is a major concern. Reduction of production cost is one of the most important ways of effective competition and increasing of productiveness of an enterprise in the modern conditions. The authors offer to evaluate the process of energy conservation in a complex way, taking into account all investment consequences: economic, technical, ecological, organizational, commercial, and others. The prospect areas of research: cost-to-use analysis from the introduction of personally developed systems of energy conservation.
\end{abstract}

KEYWORDS: Energy efficiency; Engineering systems; Investment resources; Economic evaluation; Development project.

\section{Introduction}

The analysis of effectiveness of energy-conservative measures for the choice of the best measure. This is due to the fact that energy-conservative measures require investments, notably, as a rule, significant. Besides, the effectiveness of energy-conservative measures is evaluated by a number of financial indicators of enterprise's operation, in particular, net cost. Thus, the selection of energyconservative means at increasing enterprise's energy efficiency is a multiple-option task requiring efficient criteria of evaluation.

Due to the fact that modern production enterprise is resource-constrained, a need for modeling investment consequences and detailed substantiation of each selection criteria appears. It should be also noted that energy efficiency is predominantly defined in the technology itself and in the opportunity to invest in the processes of energy consumption. Therefore, in order to demonstrate the economic efficiency of energy conservation measure we define those factors, which trace its roots from conservation systems, i.e. enhancement of efficiency in the energy context of engineering services and facilities. In this regard we'll speak of engineering systems used both in the process of enterprise operation and in the structure of technological process functioning.

Among main factors, preventing the introduction of advanced technologies at enterprise, according to authors' data and earlier researches [1], in which the majority of respondents answered (Figure 1):

\footnotetext{
* Corresponding author: Director of the Center of Tariff Regulation in the Energy Sector, Higher School of Tariff Regulation, Plekhanov Russian University of Economics; Senior Researcher at the Department of Energy Policy, Institute of Economics of the Russian Academy of Sciences, Moscow, Russian Federation. Tel: +7 (495) 958-27-43. Email address: kapitonov_ivan@mail.ru
} 
- $\quad$ limited financing $(44,2 \%)$;

- lack of research and technology support $(4,2 \%)$,

- $\quad$ unskilled staff $(3,4 \%)$,

- $\quad$ organizational and legal problems $(5,2 \%)$

- failure of managers to adopt new technologies $(4,9 \%)$;

- other problems made up 38,1\%.

\section{Figure 1}

For today, only about $12 \%$ of production enterprises practice innovations regarding the introduction of new technological processes in production, and the share of introduced resource saving technologies in the total volume of innovative solutions doesn't exceed $38 \%$ (Figure 2).

\section{Figure 2}

Modern literary sources allow choosing the necessary methods of economic efficiency calculation, but they don't cover all assessment criteria to carry out the analysis. The issue of the evaluation of economic, organizational production technical and environmental criteria in general, alternative comparison of investment in other capital investment projects is not adequately investigated $[3,4]$.

That's why the selection criteria of capital investment projects of energy saving and enhancement of methodology of determination of energy-conservative measure efficiency invite further investigations. According to the author, the totality of selection criteria of energy saving measures should be classified as follows: economic, technical, production, ecological, and organizational.

The economic criterion is the first priority step in comparison. Initial investment, financial results of the project and operating costs for implementation of this project over a certain period of time (credit and share deductions, taxes) are initial data, which characterize the investment process. The forecasting of financial results is usually made focusing on three basic scenarios: optimistic, realistic, and pessimistic. Optimistic scenario will be defined with maximum sales profit, pessimistic - with minimum.

The classification of economic criteria is carried out as follows [5]. By time factor: static, in which cash flows emerging in different periods of time are classified as equivalent, and dynamic cash flows for their comparison by the use of discounting or accumulation [6]. The absolute value of profit gained from investment process is assessed in absolute factors; in relative factors it is characterized by the ratio of financial results from their sales in the aggregate cost of goods sold; temporal - are brought to a certain period of time. By the type of generalizing indicator - absolute, relative and temporal.

\section{Literature review}

The development of enterprise, its efficient current functioning and meeting of major, long-term goals should be carried out based on an organizational-economic mechanism, which is designed to manage financial, labor, energy and other resources for the purpose of the maximum use of detected potentials [7]. The research of economic processes of energy conservation potential implementation at enterprise allows increasing the profitability of enterprise's functioning, anchoring it in the area of functioning market, reducing financial and operating risks. Country's economy grows simultaneously with the economic development of a separate enterprise [8]. A need for defining the essence of the organizational-economic mechanism of energy saving of production enterprises, substantiation of stages, criteria and principles of its formation appears. 
The essence of the "mechanism" notion is involved into the economic science from mechanics, where "mechanism" is understood as a system for transformation or transmission of motion between bodies [9]. The "economic mechanism" term obtained a wide circulation in the Soviet period, the base of which government property and planned economy were. The "organizational-economic mechanism" term can be often met in scientific literature. Recently, scientists have paid a lot of attention to the organizational-economic mechanism of energy conservation and increase of enterprise's energy efficiency, its technological processes. Turkenburg and Blok [10] considers that organizational-economic mechanism - is an aggregate of forms, methods and management tools. According to Kamušič [11], Zhou and Zhang [12] organizational-economic mechanism of energy conservation - is an aggregate of measures, which provide the maximum use of energy potential at minimum energy unit costs per output unit production. Krones [13] considers that organizationaleconomic mechanism of energy conservation at enterprise is a totality of organizational and economic levers (each of them has its own forms of management impact), which have an impact on economic and organizational parameters of enterprise, which contributes to the formation of strengthening of energy potential, obtaining competitive advantage and enterprise's operating efficiency in general. According to Klaue and Veitinger [14], organizational-economic mechanism of energy conservation is a system of interrelated economic and organizational elements focused on activization of economical expenditure of energy reserves, introduction of energy-conservative measures taking into account innovation achievements in the area, both technological and product. Spencer [15] considers that the structure of energy conservation mechanism provides legal, organizational-management, economic, and engineering aspect, the interaction of which should have a positive economic results $[16,17]$.

Organizational-economic mechanism of energy conservation should involve the following components [18]:

- management principles and tasks;

- management methods, forms and tools;

- organizational structure of enterprise's management and its staff, information and processing means.

According to the author, organizational-economic mechanism of energy conservation of production enterprise - is a totality of economic, organizational, motivational methods and means focused on economically feasible detecting and the maximum use of energy saving potential for the purpose of minimization of unit costs per product and the decrease of ecological load on the environment.

The implementation of the mechanism at enterprise should be carefully proved and estimated. Results from the introduction of organizational-economic solutions are preliminary obtained by means of mathematical simulation with regard to an aggregate of main factors of influence on the process. The growth of cost and shortage of energy resources additionally toughen the requirements to scientific rationale of the main principles of implementation of production enterprise energy conservation potential. The main attention should be divided into strategic management technologies, enterprise's technical-and-economic characteristics and its units, the methods of energy potential research and energy conservation potential and their implementation.

The main disadvantage of modern organizational-economic mechanisms in the area of assets management is their insufficient specifity and formal approach, just summing up of different offers without their unification into an integral mechanism [19], that's why it's necessary except the formation of the aggregate of the solutions of technical, organizational, economic, ecological, production area to develop efficient areas of monitoring and response to the results of its introduction for efficient implementation of the mechanism [20]. 
According to $\mathrm{Hu}$ at al. [21], ascendant basic framework and conceptual basics of such tools to support efficient management solutions in the management of the potential of the economic systems of the national economy should be nevertheless stated with the priorities of current profitability of deployed resources to provide investment attractiveness of economic subjects, that's why the use in organizational-economic mechanisms of energy conservation of industrial enterprises of economic math modeling is an indispensable condition for investing activities' efficiency within offered solutions.

\section{Methodology}

The implementation of offered concepts related to the formation of the system of energy conservation at production enterprises requires economic math modeling based on the data obtained as a result of economic-energy inspection of a production enterprise. In accordance with the standards by the procedure of energy inspection organization [22], energy auditor shall:

- $\quad$ keep the information secret, which became available to him due to energy inspection;

- not disclose information related to commercial secret, which became available to him due to energy inspection;

- obligation of confidentiality in relation to specific energy inspections, which also extend to people, who knew this confidentiality due to discharge of their duties (including experts, performing inspection of materials provided by a specialized organization).

The inspection was carried out in accordance with the structural-logical scheme of economicenergy inspection of production enterprise. A group of experts from leading specialists of corresponding units and chief engineer was formed at the enterprise [23]. The first stage of research is an analysis of financial circumstances, definition of financial soundness, liquidity, and profitability of activity. The goal of economic-energy inspection is not complete financial analysis of the enterprise but determine main key indicators for formation of the general picture of financialeconomic condition of the enterprise.

The enterprise's opportunity to implement energy saving measures can be assessed by the calculated financial stability of the enterprise: absolute and normal financial stability allows drawing a conclusion about enterprise's capacity to cover expenses for energy saving measures introduction with shareholders' equity or called-up capital. Enterprise's unstable financial situation requires detailed substantiation of the opportunity to invest in energy conservation. The crisis condition indicates failure of individual financing of measure.

The issue of substantiation of investment capital structure is incurred on enterprise's management and specialists of energy auditing group, who, basing on the financial audits' results, economic energy inspection, determine the optimal balance of means and maximum amount of financing. The calculation of annual expenditure of means for inflation development cover and exposure fee to investors when using attracted funds is carried out in parallel. Annual fixed charges for loan interest cover are also determined.

The critical value of the balance of own funds, attracted funds, stock and investment capital for financing energy conservation measures are (generalized by the author):

$$
\mathrm{WC}+\mathrm{LO}<\mathrm{ST}+\mathrm{I}_{\mathrm{e}}<\mathrm{WC}+\mathrm{LO}+\mathrm{SO}
$$

where WC - enterprise's working capital; LO, SO - long-term and short-term obligations; ST - stock; $\mathrm{I}_{\mathrm{e}}$ - investment in energy conservation measures.

In case of the balance of enterprise's assets, which is described by inequality (1), a situation is in place when attraction of credit facilities is necessary to finance energy conservation measures. For 
today, it's problematic to acquire long-term credits for enterprises, that's why the main stake is placed on short-term loans.

However, enterprise's situation when the cost of stock and investment capital is lower than own funds or own funds and long-term obligations:

$$
\begin{aligned}
& \mathrm{ST}+\mathrm{I}_{\mathrm{e}}<\mathrm{WC}+\mathrm{LO} \\
& \mathrm{ST}+\mathrm{I}_{\mathrm{e}}<\mathrm{WC}
\end{aligned}
$$

is more preferable from the enterprise's economic security's point. Then the enterprise can provide investing of energy conservation projects on its own.

Formula (1) is a critical condition of energy conservation measures' implementation, i.e. balance when enterprise's stocks and investments in energy conservation measures are higher than enterprise's working capital and long-term obligations. That said, providing the additional attraction of short-term credits and loans, the sum of stocks and investment shouldn't exceed the sum of working capital, long-term and short-tem obligations.

\section{Results and discussions}

Along with this, the enterprise's financial situation, which meets inequalities (2)-(3) conditions, is more acceptable from the point of enterprise's economic security. This is explained by the fact that providing the meeting of the conditions of these inequalities the enterprise will have the opportunity to carry out financing of both daily operations and activities related to energy-conservative measures on its own.

Tables 1-3 below summarize main financial indicators of enterprise's activity, which are recommended to use during economic energy inspection.

\section{Table 1}

Three-component exponent allows evaluating the type of enterprise's financial stability and drawing conclusions on the opportunity to finance energy conserving measures. The author also recommends determining the value of financial stability coefficient, which allows assessing the type of enterprise's financial stability and drawing conclusions on the opportunity to finance energy conserving measures and financial risk coefficient, which is designed to analyze the opportunity to attract debt capital for financing energy-conservative measures.

Besides financial stability, the condition of liquidity and profitability of enterprise's activity is of interest. Indicators characterizing the enterprise's liquidity and which are expedient to use for financial analysis at economic energy inspection are given in Table 2.

\section{Table 2}

Cover ratio, quick ratio and absolute liquidity ratio belong to such indicators - they characterize enterprise's paying capacity at the expense of attraction of resources in settlements or absolute floating assets, in particular, in regard to financing energy conservative measures.

Enterprise's profitability allows evaluating the opportunity to use own funds for energy conservation investment, as well as distribution of specific incomes by different types of enterprise's activity. The main indicators of profitability, which are recommended to use for enterprise's financial analysis during economic-energy inspection, are as follows: operational activities profitability, economic activity profitability, assets profitability, shareholders' equity profitability, called-up capital profitability (Table 3 ).

\section{Table 3}

First two indicators characterize profit from 1 rouble of operating and general costs, components of which are energy products. The more profit from operating and general costs, the 
less energy products' cost influence, and, correspondingly, measures of energy conservation for the enterprise.

The profitability of shareholders' equity and called-up capital characterizes the potential opportunities enterprise's management to efficiently use shareholders' equity and called-up capital, and specialists, who carry out energy inspection - evaluate the expediency of the usage of called-up capital at investing energy saving projects. Although the question of investment capital structure doesn't directly belong to the competence and tasks of energy managers, the estimation of confidence and correctness of chosen resources of financing is their obligation [24, 25].

When using investment schemes based on the use of attracted funds, the efficiency of solutions by enterprise's credit policy is the base of general success of all scheme of financing. The analysis of enterprises' financial indicators shows that their majority is in critical or precritical condition, that's why implementation of measures regarding energy conservation increase is necessary and well-timed (Table 4).

However, the enterprises' critical financial condition compels to the search for efficient measures of energy conservation, which would provide possibility to make most profit (saving resources, energy products and means) with minimum capital investment. After the evaluation of the enterprise's ability to finance energy saving measures, the management defines the structure and value of investment capital. The schemes of financing of energy saving measures are also determined and modeling to determine the priority for introduction of a set of energy conservation measures is carried out.

\section{Table 4}

Investment capital in the amount of $2 \mathrm{mln}$ roubles, composing of $1 \mathrm{mln}$ own funds and $1 \mathrm{mln}$ attracted credit funds at $23 \%$ per year, is taken for each enterprise for the purpose of equivalence of carrying out of accounting results analysis.

By the results of economic-energy inspection ten technical energy-conservative measures requiring investment were offered to be introduced at researched seven enterprises:

- Increasing resistance of thermal insulation of envelope building (heating-up) of workshop premises and administration building [26].

- Heating-up of pipe-lines of enterprise's heat supply system.

- Installation of wasteheat exchangers in ventilation system.

- Replacement of boiler equipment in boiler-room.

- Disposal of warmth of boiler-room furnace gases.

- Replacement of processing facilities engines to less powerful ones.

- Replacement of illumination device to energy-conservative ones.

- Replacement of compressor equipment and air pipes of process air supply system.

- Replacement of windows to energy-conservative ones.

- Installation of air sheets on the gate.

Each of mentioned measures can be introduced at all or individual business units [27]. For each business unit of specified enterprise necessary investments are determined to implement a measure of energy conservation. The value of annual saving of resources is calculated for each from chosen measures.

The first and second options of calculation are given in Tables 5 and 6 . The first and second options of calculation are given for Workshop No. 1 of machine builder for measures No. 1-10.

\section{Tables 5, 6}

Own tariffs for energy products and tax treatment should be taken into account for each enterprise. Other economic effects indirectly related to energy resource saving can be taken into 
account at calculations. The value of emission cuts can be determined analytically - by means of corresponding ecological calculations and practically - as a result of measurements by gas sensor of concentration of corresponding gases. As a result of calculations a summary table is compiled for each enterprise. The option for the first enterprise is given in Table 7.

\section{Table 7}

Annual saving of means due to possible implementation of energy saving measure and necessary investment means to implement this measure at given unit are entered into the summary table by each measure for each unit.

The priority totality of energy saving measures for each enterprise providing investment resource limit at $2 \mathrm{mln}$. roubles is chosen by the method of dynamical programming by means of blind search of elements from Table 7. For the purpose of distribution of energy-conservative factors in accordance with the value of investment attractiveness based on the calculation results in accordance with the totality of above-mentioned economic, technical and exploitation criteria, the next step is modeling of the second stage - in the fuzzy model of intellectual decision support.

For the first option of calculation (Figure 3) the maximum annual saving will make up 5,730 $\mathrm{mln}$. roub. under the terms of $2 \mathrm{mln}$. roub. investment. The need for gradation of energy saving measures determined based on the first stage of modeling energy saving measures by investment attractiveness appears the second stage. Energy auditing group calculates the value of necessary investment for implementation of each measure basing on the average prices of materials and cost of work in a certain region.

\section{Figure 3}

In Table 7 cells with the numbers of priority measures to implement according to the first stage of calculation are marked. To switch to the next step a need for calculating complete economic effect (CEE) for each of priority measures appears. The life term of all measures is different, that's why periods of investing at calculating CEE is different for each measure. We distinguish three periods: short-term, middle-term and long-term.

In CEE calculations it's accepted that the share of reinvested profit makes up $30 \%$, earning power of reinvestment $15 \%$ per year. The cost of the project for first measure is zero, since the repeated use of mounted thermal insulation is almost impossible. For all other measures the use of installed materials and equipment appears possible in any year of project consideration, that's why the cost of the project is calculating based on the cost of initial investment and value of moral and physical deterioration.

The calculation of complete economic effect for measure No.6 is given in Table 8, and the option of calculation fuel and energy resources (FER) for measure No.1 - in Table 9. In the column "payment to investor" annual fixed amount is given, which is paid to investor as interest by the credit. According to credit conditions, enterprises are given funds in the amount of 1 million roubles at $23 \%$ per year. Each investment capital correspondingly consists of own funds and borrowed funds in the ratio 50/50. According to Figure 3 the optimal value of resulting function (cost cutting) makes up 5730 thous. roubles, optimal projects for implementation at corresponding business units 1-6-33-1-5-1.

\section{Tables 8, 9}

The general investment resource, which is necessary to spend on the implementation of specified measures doesn't exceed the chosen value at $2 \mathrm{mln}$. roubles. Thus, the first stage of calculation can be considered successful.

Let's consider the comparison of results of calculation of economic effect from the implementation of energy saving measures using different methods. The first method - the 
calculation of complete economic effect offered by the author, CEE made up 1,560 mln. roubles over 10 years; the second - traditional based on discounting. In accordance with initial conditions of modeling let's determine net present value of such measure with reinvesting and exclusively of reinvestment. The calculated coefficient of discounting is $r=0,115$. The results of comparison of calculation results using different methods are graphically given in Fig.4. The calculation is carried out for the period of project life term - 10 years. As it seen from Fig. 4 when comparing short-term and middle-term periods of implementing energy saving measure, results of calculation NPV with reinvesting and CEE are almost the same.

\section{Figure 4}

The significant difference is observed at long-term periods of project life. In this case discrepancy between results is significant. Pay-off period in all calculation options is about 4,5 years. Such significant discrepancy in long-term period is explained by fast depreciation of obtained financial results at discounting cash flows. Despite the trifling value of project as compared to economic effects obtained from the introduction of measure, the curve of CEE including project cost and CEE exclusive of project cost almost coincide.

Thus, a conclusion can be drawn on the better integrity and adequacy of reflection of economic effects of introduction of energy saving measures using the method of complete economic effect. The analysis of expert information in the mathematical model based on the theory of fuzzy logic and linguistic variable allowed determining the values of the indicator of investment attractiveness of each of chosen energy saving measures. The option of determining X parameter economic factors are given in Table 10. L parameter value is given in Table 11.

\section{Tables 10, 11}

The analysis of calculated totality of priority measures at enterprises where economic energy inspection was carried out allowed forming a number of priority measures of energy saving in the technical field (Figure 5):

- Increasing resistance of thermal insulation of envelope building (heating-up) of workshop premises and administration building.

- Heating-up of pipe-lines of enterprise's heat supply system;

- Installation of wasteheat exchangers in ventilation system;

- Replacement of boiler equipment in boiler-room;

- Disposal of warmth of boiler-room furnace gases;

- Replacement of processing facilities engines to less powerful ones;

- Replacement of illumination device to energy-conservative ones;

- Replacement of compressor equipment and air pipes of process air supply system;

- Replacement of windows to energy-conservative ones;

- Installation of air sheets on the gate.

\section{Figure 5}

The decrease in the consumption of energy resources, the improvement of ecological situation, the decrease in fixed costs of production enterprise and, as a consequence, higher profitability can be achieved by the introduction of energy-saving measures. Investment in energy-conservation is profitable for enterprises, because the issues of ecology, improvement of inner microclimate, decrease in social tension, etc. are being solved simultaneously with earning power growth. The implementation of energy-saving measures requires enterprise's management interest, staff motivation, the presence of skilled staff, financial possibilities, and other factors. 
The introduction of energy-saving measures at production enterprise should be carried out involving the majority of workers, because the efforts of management may come to nought without staff support. The main instrument of general public attraction to the policy of energy conservation is staff motivation using different approaches and theories.

\section{Conclusions}

The analysis of the space of priority measures of energy conservation indicates the decisive superiority of thermo modernization of buildings and facilities, as well as a set of other measures, which can be unified under the general title "The use of the potential of enterprise's secondary energy reserves".

The introduction of efficient scheme of energy saving measures within the framework of organizational-economic mechanism of energy conservation at production enterprises should be accompanied by a complex of actions focused on the diversification of power supply sources, switch to complex power supply with a combination of traditional and alternative sources or complete switch to alternative sources. Attention should be also paid to the questions of the use of the potential of secondary power resources and their practical use at enterprise, enterprise's staff motivation to energy conservation.

\section{References}

1. Sun, L. "Adaptive efficiency and the evolving diversity of enterprise ownership and governance forms: An overview", In Ownership and Governance of Enterprises: Recent Innovative Developments, pp. 1-35, Palgrave Macmillan UK, London (2003).

2. Cagno, E., Trianni, A., Spallina, G. and Marchesani, F. "Erratum to: Drivers for energy efficiency and their effect on barriers: Empirical evidence from Italian manufacturing enterprises", Energy Efficiency, 10(4), p. 871 (2017).

3. Banalieva, E.R., Santoro, M.D. and Jiang, J.R. "Home region focus and technical efficiency of multinational enterprise", Management International Review, 52(4), pp. 493-518 (2012).

4. Ghaebi, H., Bahadori, M.N. and Saidi, M.H. "Economic and environmental evaluations of different operation alternatives of an aquifer thermal energy storage in Tehran, Iran", Scientia Iranica, 24(2), pp. 610-623 (2017).

5. Alkaya, E. and Demirer, G.N. "Improving resource efficiency in surface coating/painting industry: Practical experiences from a small-sized enterprise", Clean Technologies and Environmental Policy, 16(8), pp. 1565-1575 (2014).

6. Alford, B.W.E. "Factors in business enterprise and efficiency", In Depression and Recovery? British Economic Growth 1918--1939, pp. 45-56, Macmillan Education UK, London (1972).

7. Vernon, R. "United states enterprise in the less developed countries: Evaluation of cost and benefit", In The Gap Between Rich and Poor Nations, pp. 215-244, Palgrave Macmillan UK, London (1972).

8. Sridhar, K.S. "Benefits and Costs of Regional Development: Evidence from Ohio's Enterprise Zone Programme." In Incentives for Regional Development: Competition Among SubNational Governments, pp. 87-114, Palgrave Macmillan UK, London (2005).

9. Hinds, S., Sanchez, N. and Schap, D. "Public enterprise: Retrospective review and prospective theory", In Handbook of Public Finance, pp. 277-300, Springer US, Boston, MA (2005).

10. Turkenburg, W.C, and Blok, K. "Towards a method for assessing long-term opportunities for energy-efficiency improvement”, In Potential for Industrial Energy-Efficiency Improvement in the Long Term, pp. 13-42, Springer Netherlands, Dordrecht (2000).

11. Kamušič, M. "Economic efficiency and workers' selfmanagement", In Yugoslav Workers' Selfmanagement, pp. 76-116, Springer Netherlands, Dordrecht (1970). 
12. Zhou, H. and Zhang, J. "From "Enterprise Insurance" to Social Insurance", In Towards a Society with Social Protection for All: A Concise History of Social Security Transformation in Modern China, pp. 39-91, Springer Singapore, Singapore (2017).

13. Krones, M. "Method to identify energy efficiency measures for factory systems", In A Method to Identify Energy Efficiency Measures for Factory Systems Based on Qualitative Modeling, pp. 71-125, Springer Fachmedien Wiesbaden, Wiesbaden (2017).

14. Klaue, T. and Veitinger, M. "Flexible manufacturing and it's benefits for the financial situation of an enterprise", In Computer-Based Management of Complex Systems, pp. 119127, Springer Berlin Heidelberg, Berlin, Heidelberg (1989).

15. Spencer, D.L. "Advantages of mixed enterprise to the public sector", In India, Mixed Enterprise and Western Business: Experiments in Controlled Change for Growth and Profit, pp. 175-194, Springer Netherlands, Dordrecht (1959).

16. Kaveh, A. and Nasrollahi, A. "Charged system search and particle swarm optimization hybridized for optimal design of engineering structures", Scientia Iranica, 21(2), pp. 295-305 (2014).

17. Portella, C.M. de M.A., Cavalcanti, E.H.S., Resende, V.L.D., Silva, F. dos S. and Simoes, M.G.P. de A. "Realignment of quality management system for improving the reliability of a biofuel laboratory", Periódico Tchê Química, 14(27), pp. 75-83 (2017).

18. $\mathrm{Hu}, \mathrm{Z}$., Han, X. and Wen, Q. "The backbone of DSM implementation: Energy service companies", In Integrated Resource Strategic Planning and Power Demand-Side Management, pp. 287-384, Springer Berlin Heidelberg, Berlin, Heidelberg (2013).

19. Stich, V., Brandenburg, U. and Kropp, S. "Benchmarking concept for energy efficiency in the manufacturing industry: A holistic energy efficiency model", In Advances in Production Management Systems. Value Networks: Innovation, Technologies, and Management, pp. 390395, Springer Berlin Heidelberg, Berlin, Heidelberg (2012).

20. Li, G., Kong, J., Xie, L. and Jiang, G. "Energy efficiency evaluation for iron and steel high energy consumption enterprise", In Information and Automation, pp. 684-690, Springer Berlin Heidelberg, Berlin, Heidelberg (2011).

21. $\mathrm{Hu}, \mathrm{Z}$., Han, X. and Wen, Q. "The implementers of demand-side management: Power grid enterprises", In Integrated Resource Strategic Planning and Power Demand-Side Management, pp. 219-286, Springer Berlin Heidelberg, Berlin, Heidelberg (2013).

22. Thollander, P. and Palm, J. "Improving energy efficiency in industrial SMEs", In Improving Energy Efficiency in Industrial Energy Systems: An Interdisciplinary Perspective on Barriers, Energy Audits, Energy Management, Policies, and Programs, pp. 15-34, Springer London, London (2013).

23. Li, M. "Analysis of industrial security based on the theoretical frame of industrial economics", In Research on Industrial Security Theory, pp. 171-240, Springer Berlin Heidelberg, Berlin, Heidelberg (2013).

24. Abolarin, S.M. "An economic evaluation of energy management opportunities in a medium scale manufacturing industry in Lagos", International Journal of Engineering Research in Africa, 14, pp. 97-106 (2015).

25. Procaccianti, G., Fernández, H. and Lago, P. "Empirical evaluation of two best practices for energy-efficient software development", The Journal of Systems and Software, 117, pp. 185198 (2016).

26. Girya, L.V., Sheina, S.G. and Fedyaeva, P.V. "The procedure of substantiation of selection of the energy-efficient design solutions for residential buildings", International Journal of Applied Engineering Research, 10(8), pp. 19263-19276 (2015).

27. Yu, X.-P. and Liao, X.-F. "Study on the multi-target system of building energy efficiency engineering in China", Advanced Materials Research, 962-965, pp. 1480-1484 (2014). 


\section{Captions}

Table 1. Indicators, characterizing financial stability and which are reasonable to use for enterprise's financial analysis at economic-energy inspection.

Table 2. Indicators characterizing the enterprise's liquidity and which are expedient to use for financial analysis at economic energy inspection.

Table 3. The main indicators of profitability, which are expedient to use for enterprise's financial analysis during economic-energy inspection.

Table 4. Results of the analysis of financial condition of machine builder within the framework of economic-energy inspection.

Table 5. The first option of calculation of annual cost cutting due to energy-conservative measures at Enterprise 1 (developed by the author).

Table 6. The second option of calculation of annual cost cutting due to energy-conservative measures at Enterprise 1.

Table 7. The first option of summary table of calculation of annual saving from energy-conservative measures at Enterprise 1 and necessary investment resources for their implementation.

Table 8. Calculation of complete economic effect of energy saving measure "Replacement of equipment engines to less powerful ones" of Enterprise 1.

Table 9. The second variant of calculation of complete economic effect of energy saving measure "Increasing envelope building thermal insulation resistance" Enterprise 1" (developed by the author).

Table 10. The first option of calculation of the components of the indicator of investment attractiveness of energy saving measure at enterprise (developed by the author).

Table 11. The second option of calculation of the components of the indicator of investment attractiveness of energy saving measure at enterprise (parameter L value).

Figure 1. Distribution of factors preventing the introduction of advanced technologies, in $\%$ from the total number of enterprises (compiled by the author).

Figure 2. Dynamics of introduction of innovations at production enterprises [2].

Figure 3. Results of calculation of the first stage of modeling of the option of priority measures of energy conservation for enterprise.

Figure 4. Graphic interpretation of results of calculation of CEE and NPV at investing in energy saving measure with the use of different methods (at project zero cost) (developed by the author).

Figure 5. Priority measures of energy saving, which are recommended to be introduced at the units of production enterprises based on the results of economic energy inspection

Ivan A. Kapitonov is a director of the Center of Tariff Regulation in the Energy Sector of the Higher School of Tariff Regulation of the Plekhanov Russian University of Economics. He is a Senior Researcher of the Department of Energy Policy of Institute of Economics of the Russian Academy of Sciences since 2007. He defended his PhD thesis at the Diplomatic Academy of the Ministry of Foreign Affairs of the Russian Federation in the direction of "World Economy" in 2006. $\mathrm{He}$ is an associate professor in the specialty "World Economy" since 2016. He is the author of more than 100 articles, 5 monographs (one of them is co-authored), 4 textbooks (one of them is coauthored), numerous reports on international and regional energy and the global economy conferences. He is also a member of editorial board at 2 regular scientific periodicals at the Institute of International Economic Relations and Diplomatic Academy of the Ministry of Foreign Affairs of the Russian Federation. 
Table 1. Indicators, characterizing financial stability and which are reasonable to use for enterprise's financial analysis at economic-energy inspection.

\begin{tabular}{|c|c|c|}
\hline Indicator & Economic content and calculation formula & $\begin{array}{l}\text { Assignment in economic energy } \\
\text { inspection }\end{array}$ \\
\hline $\begin{array}{l}\text { Own circulating assets } \\
\text { OCA }\end{array}$ & $\begin{array}{l}\text { A difference between shareholders' equity and } \\
\text { enterprise's non-current assets }\end{array}$ & $\begin{array}{l}\text { Allows estimating the enterprise's } \\
\text { capacity to finance energy conservation } \\
\text { measures without raising debt }\end{array}$ \\
\hline Working capital WK & $\begin{array}{l}\text { Enterprise's shareholders' equity, increased by } \\
\text { the value of long-term liability }\end{array}$ & $\begin{array}{l}\text { The same but with attraction of long- } \\
\text { term loan obligations }\end{array}$ \\
\hline General funds GF & $\begin{array}{l}\text { Enterprise's working capital, increased by the } \\
\text { value of short- term bank credits }\end{array}$ & $\begin{array}{l}\text { The same but with attraction of long- } \\
\text { term and short-term loan obligations }\end{array}$ \\
\hline $\begin{array}{l}\text { Three-component } \\
\text { exponent } \mathrm{S}\end{array}$ & $\begin{array}{l}\text { Allows evaluating the type of enterprise's } \\
\text { financial stability: }\end{array}$ & $\begin{array}{l}\text { Allows evaluating the type of } \\
\text { enterprise's financial stability and } \\
\text { drawing conclusions on the opportunity } \\
\text { to finance energy conserving measures }\end{array}$ \\
\hline $\begin{array}{l}\text { Equity to Total Assets } \\
\text { coefficient } \mathrm{K}_{\mathrm{eta}} \\
\text { Financial risk coefficient } \\
\mathrm{K}_{\mathrm{fr}}\end{array}$ & $\begin{array}{l}\text { Characterizes shareholders' equity } \\
\text { concentration } \\
\text { Characterizes debt to equity ratio }\end{array}$ & $\begin{array}{l}\text { Allows drawing conclusions on the } \\
\text { opportunity to attract debt capital for } \\
\text { financing energy-conservative } \\
\text { measures }\end{array}$ \\
\hline
\end{tabular}

Table 2. Indicators characterizing the enterprise's liquidity and which are expedient to use for financial analysis at economic energy inspection.

\begin{tabular}{|c|c|c|}
\hline Indicator & $\begin{array}{l}\text { Economic content and calculation } \\
\text { formula }\end{array}$ & Assignment in economic energy inspection \\
\hline $\begin{array}{l}\text { Coverage coefficient } \\
\text { Kp } \\
\text { Quick ratio Klsh }\end{array}$ & $\begin{array}{l}\text { characterizes the ratio of working assets } \\
\text { to current liabilities } \\
\text { characterizes the ratio of resources in } \\
\text { settlements of current liabilities }\end{array}$ & $\begin{array}{l}\text { Characterizes the enterprise's paying capacity at } \\
\text { the expense of attraction of resources in } \\
\text { settlements in regard to financing energy } \\
\text { conservative measures }\end{array}$ \\
\hline $\begin{array}{l}\text { Absolute liquidity } \\
\text { ratio Klabs }\end{array}$ & $\begin{array}{l}\text { characterizes the enterprise's ability to } \\
\text { settle accounts by current liabilities with } \\
\text { absolute floating assets }\end{array}$ & \\
\hline
\end{tabular}

Table 3. The main indicators of profitability, which are expedient to use for enterprise's financial analysis during economic-energy inspection.

\begin{tabular}{lcl}
\hline \multicolumn{1}{c}{ Indicator } & Economic content and calculation formula & $\begin{array}{c}\text { Assignment in economic- } \\
\text { energy inspection }\end{array}$ \\
\hline $\begin{array}{l}\text { Operational activities } \\
\text { profitability, \% }\end{array}$ & $R o=F R O D C+A V+V Z+I O B \times 100 \%$ & $\begin{array}{l}\text { Characterizes profit from 1 } \\
\text { rouble of operating costs, } \\
\text { costs for energy products } \\
\text { also belong to }\end{array}$ \\
$\begin{array}{l}\text { Economic activity } \\
\text { profitability, \% }\end{array}$ & $R g o s p=C H P C+A V+V Z+O I B+V F+V K+I V+V N D \times 100 \%$ & $\begin{array}{l}\text { Characterizes profit from 1 } \\
\text { rouble of general expenses, } \\
\text { costs for energy products } \\
\text { also belong to }\end{array}$ \\
Assets profitability, \% & $R a=F R Z D o p A \times 100 \%$ & $\begin{array}{l}\text { Characterizes profit margin } \\
\text { per 1 rouble of enterprise's } \\
\text { assets }\end{array}$ \\
\hline
\end{tabular}




\begin{tabular}{lll}
\hline $\begin{array}{l}\text { Shareholders' equity } \\
\text { profitability, \% }\end{array}$ & $R v k=C H P V K \times 100 \%$ & $\begin{array}{l}\text { Characterizes profit margin } \\
\text { (loss) per 1 rouble of } \\
\text { shareholders' equity }\end{array}$ \\
$\begin{array}{l}\text { Called-up capital } \\
\text { profitability, \% }\end{array}$ & $R z k=C H P Z K \times 100 \%$ & $\begin{array}{l}\text { Characterizes profit margin } \\
\text { (loss) per 1 rouble of } \\
\text { called-up capital }\end{array}$ \\
\hline
\end{tabular}

Table 4. Results of the analysis of financial condition of machine builder within the framework of economicenergy inspection.

\begin{tabular}{|c|c|c|c|c|c|c|}
\hline Year & Indicator & Enterprise 1 & Enterprise 2 & Enterprise 3 & Enterprise 4 & Enterprise 5 \\
\hline 2013 & \multirow{5}{*}{ Cover ratio } & 1,29 & 0,70 & 4,44 & 2,38 & 3,42 \\
\hline 2014 & & 1,38 & 0,31 & 4,53 & 2,86 & 2,74 \\
\hline 2015 & & 2,04 & 0,34 & 3,60 & 2,25 & 1,99 \\
\hline 2016 & & 1,71 & 0,41 & 2,80 & 3,25 & 2,08 \\
\hline 2017 & & 2,10 & 0,21 & 3,98 & 2,07 & 1,74 \\
\hline 2013 & \multirow{5}{*}{ Quick ratio } & 0,82 & 0,14 & 1,05 & 2,03 & 0,90 \\
\hline 2014 & & 0,78 & 0,07 & 0,92 & 2,50 & 0,88 \\
\hline 2015 & & 1,41 & 0,10 & 0,73 & 1,93 & 0,69 \\
\hline 2016 & & 0,75 & 0,12 & 0,48 & 2,90 & 0,62 \\
\hline 2017 & & 1,16 & 0,09 & 1,14 & 1,79 & 0,57 \\
\hline 2013 & \multirow{5}{*}{$\begin{array}{c}\text { Absolute } \\
\text { liquidity ratio }\end{array}$} & 0,21 & 0,002 & 0,31 & 0,40 & 0,01 \\
\hline 2014 & & 0,10 & 0,001 & 0,03 & 0,48 & 0,00 \\
\hline 2015 & & 0,24 & 0,005 & 0,01 & 0,34 & 0,04 \\
\hline 2016 & & 0,04 & 0,002 & 0,01 & 0,49 & 0,00 \\
\hline 2017 & & 0,12 & 0,002 & 0,07 & 0,25 & 0,00 \\
\hline 2013 & \multirow{5}{*}{$\begin{array}{l}\text { Operational } \\
\text { activities } \\
\text { profitability }\end{array}$} & 6,51 & 1,61 & 4,21 & 1,77 & 1,43 \\
\hline 2014 & & 7,63 & $-9,85$ & 2,79 & 2,95 & $-26,97$ \\
\hline 2015 & & 13,31 & 1,34 & 3,62 & 2,75 & $-13,01$ \\
\hline 2016 & & 14,64 & $-8,96$ & 3,41 & 3,53 & 6,02 \\
\hline 2017 & & 5,69 & $-24,49$ & 3,57 & 2,98 & $-10,30$ \\
\hline 2013 & \multirow{5}{*}{$\begin{array}{l}\text { Return on } \\
\text { economic } \\
\text { activities }\end{array}$} & 0,84 & 0,36 & 2,57 & 0,52 & 0,85 \\
\hline 2014 & & 3,89 & $-10,65$ & 1,12 & 1,44 & $-25,67$ \\
\hline 2015 & & 9,61 & 0,97 & 1,74 & 1,33 & $-11,67$ \\
\hline 2016 & & 3,37 & $-9,54$ & 1,46 & 1,11 & 6,07 \\
\hline 2017 & & 0,89 & $-24,47$ & 1,84 & 0,92 & $-11,44$ \\
\hline 2013 & \multirow{5}{*}{ Return on assets } & 1,50 & 0,51 & 4,46 & 7,95 & 0,61 \\
\hline 2014 & & 7,91 & $-6,86$ & 1,87 & 38,22 & $-12,73$ \\
\hline 2015 & & 20,23 & 1,11 & 3,27 & 30,01 & $-10,61$ \\
\hline 2016 & & 5,82 & $-9,26$ & 2,65 & 24,79 & 5,38 \\
\hline 2017 & & 1,61 & $-36,63$ & 4,00 & 14,64 & $-6,79$ \\
\hline
\end{tabular}




\begin{tabular}{|c|c|c|c|c|c|c|}
\hline 2013 & & 2,53 & 5,08 & 5,27 & 12,89 & 0,73 \\
\hline 2014 & \multirow{4}{*}{$\begin{array}{c}\text { Return on } \\
\text { shareholders' } \\
\text { equity }\end{array}$} & 12,39 & $-151,03$ & 2,22 & 56,99 & $-15,81$ \\
\hline 2015 & & 28,21 & 28,15 & 4,13 & 48,48 & $-14,47$ \\
\hline 2016 & & 9,42 & 168,39 & 3,70 & 34,41 & 7,42 \\
\hline 2017 & & 2,25 & 82,51 & 4,98 & 23,80 & $-10,06$ \\
\hline 2013 & \multirow{5}{*}{$\begin{array}{l}\text { Return on called- } \\
\text { up capital }\end{array}$} & 3,68 & 0,56 & 29,13 & 20,75 & 3,67 \\
\hline 2014 & & 21,85 & $-7,19$ & 11,86 & 116,00 & $-65,22$ \\
\hline 2015 & & 71,60 & 1,16 & 15,69 & 78,80 & $-39,80$ \\
\hline 2016 & & 15,26 & $-8,78$ & 9,35 & 88,66 & 19,63 \\
\hline 2017 & & 5,66 & $-25,37$ & 20,32 & 38,03 & $-20,92$ \\
\hline 2013 & \multirow{5}{*}{$\begin{array}{l}\text { Equity to total } \\
\text { assets }\end{array}$} & 0,59 & 0,10 & 0,85 & 0,62 & 0,83 \\
\hline 2014 & & 0,64 & 0,05 & 0,84 & 0,67 & 0,80 \\
\hline 2015 & & 0,72 & 0,04 & 0,79 & 0,62 & 0,73 \\
\hline 2016 & & 0,62 & $-0,06$ & 0,72 & 0,72 & 0,73 \\
\hline 2017 & & 0,72 & $-0,44$ & 0,80 & 0,62 & 0,68 \\
\hline 2013 & \multirow{5}{*}{$\begin{array}{c}\text { Financial risk } \\
\text { coefficient }\end{array}$} & 0,69 & 9,04 & 0,18 & 0,62 & 0,20 \\
\hline 2014 & & 0,57 & 21,01 & 0,19 & 0,49 & 0,24 \\
\hline 2015 & & 0,39 & 24,29 & 0,26 & 0,62 & 0,36 \\
\hline 2016 & & 0,62 & $-19,18$ & 0,40 & 0,39 & 0,38 \\
\hline 2017 & & 0,40 & $-3,25$ & 0,25 & 0,63 & 0,48 \\
\hline 2013 & \multirow{5}{*}{$\begin{array}{c}\text { Own circulating } \\
\text { assets }\end{array}$} & 5382,00 & $-2169,00$ & 21208,00 & 534,80 & 5808,00 \\
\hline 2014 & & 7219,00 & $-4287,00$ & 23053,00 & 1327,00 & 4422,00 \\
\hline 2015 & & 21734,00 & $-3919,00$ & 24938,00 & 2168,90 & 3304,00 \\
\hline 2016 & & 26479,00 & $-3992,00$ & 2882,00 & $-30636,12$ & 4048,00 \\
\hline 2017 & & 26114,00 & $-5157,00$ & 5880,00 & $-29810,80$ & 3183,00 \\
\hline 2013 & \multirow{5}{*}{$\begin{array}{l}\text { Return on } \\
\text { shareholders' } \\
\text { equity }\end{array}$} & 5592,00 & $-1850,00$ & 21221,00 & 534,80 & 5808,00 \\
\hline 2014 & & 7428,00 & $-4056,00$ & 23053,00 & 1327,00 & 4422,00 \\
\hline 2015 & & 21947,00 & $-3694,00$ & 24938,00 & 2168,90 & 3304,00 \\
\hline 2016 & & 26688,00 & $-3784,00$ & 2882,00 & $-30636,12$ & 4048,00 \\
\hline 2017 & & 26114,00 & $-4930,00$ & 5880,00 & $-29810,80$ & 3183,00 \\
\hline 2013 & \multirow[t]{5}{*}{ Attracted funds } & 5592,00 & $-1850,00$ & 21721,00 & 534,80 & 5808,00 \\
\hline 2014 & & 12610,00 & $-4056,00$ & 26613,00 & 1327,00 & 4422,00 \\
\hline 2015 & & 24290,00 & $-3694,00$ & 28442,00 & 2168,90 & 3304,00 \\
\hline 2016 & & 45607,00 & $-3784,00$ & 7882,00 & $-30636,12$ & 4048,00 \\
\hline 2017 & & 34140,00 & $-4930,00$ & 5890,00 & $-29810,80$ & 3233,00 \\
\hline 2013 & \multirow[t]{3}{*}{ Stocks } & 8985,00 & 3509,00 & 20910,00 & 137,50 & 6058,00 \\
\hline 2014 & & 11661,00 & 1379,00 & 23575,00 & 260,50 & 4727,00 \\
\hline 2015 & & 13303,00 & 1323,00 & 27557,00 & 566,40 & 4332,00 \\
\hline
\end{tabular}




\begin{tabular}{|c|c|c|c|c|c|c|}
\hline 2016 & & 36098,00 & 1903,00 & 34131,00 & 506,67 & 5470,00 \\
\hline 2017 & & 22383,00 & 723,00 & 27250,00 & 594,97 & 5021,00 \\
\hline 2013 & \multirow{5}{*}{$\begin{array}{l}+/ \text { - own working } \\
\text { capital for stock } \\
\text { formation }\end{array}$} & $-3603,00$ & $-5678,00$ & 298,00 & 397,30 & $-250,00$ \\
\hline 2014 & & $-4442,00$ & $-5666,00$ & $-522,00$ & 1066,50 & $-305,00$ \\
\hline 2015 & & 8431,00 & $-5242,00$ & $-2619,00$ & 1602,50 & $-1028,00$ \\
\hline 2016 & & $-9619,00$ & $-5895,00$ & $-31249,00$ & $-31142,79$ & $-1422,00$ \\
\hline 2017 & & 3731,00 & $-5880,00$ & $-21370,00$ & $-30405,78$ & $-1838,00$ \\
\hline 2013 & \multirow{5}{*}{$\begin{array}{l}+/- \text { working } \\
\text { capital for stock } \\
\text { formation }\end{array}$} & $-3393,00$ & $-5359,00$ & 311,00 & 397,30 & $-250,00$ \\
\hline 2014 & & $-4233,00$ & $-5435,00$ & $-522,00$ & 1066,50 & $-305,00$ \\
\hline 2015 & & 8644,00 & $-5017,00$ & $-2619,00$ & 1602,50 & $-1028,00$ \\
\hline 2016 & & $-9410,00$ & $-5687,00$ & $-31249,00$ & $-31142,79$ & $-1422,00$ \\
\hline 2017 & & 3731,00 & $-5653,00$ & $-21370,00$ & $-30405,78$ & $-1838,00$ \\
\hline 2013 & \multirow{5}{*}{$\begin{array}{l}+/ \text { - general funds } \\
\text { for stock } \\
\text { formation }\end{array}$} & $-3393,00$ & $-5359,00$ & 811,00 & 397,30 & $-250,00$ \\
\hline 2014 & & 949,00 & $-5435,00$ & 3038,00 & 1066,50 & $-305,00$ \\
\hline 2015 & & 10987,00 & $-5017,00$ & 885,00 & 1602,50 & $-1028,00$ \\
\hline 2016 & & 9509,00 & $-5687,00$ & $-26249,00$ & $-31142,79$ & $-1422,00$ \\
\hline 2017 & & 11757,00 & $-5653,00$ & $-21360,00$ & $-30405,78$ & $-1788,00$ \\
\hline 2013 & \multirow{5}{*}{$\begin{array}{l}\text { Three- } \\
\text { component } \\
\text { exponent }\end{array}$} & critical & critical & absolute & absolute & critical \\
\hline 2014 & & Pre critical & critical & Pre critical & absolute & critical \\
\hline 2015 & & absolute & critical & Pre critical & absolute & critical \\
\hline 2016 & & Pre critical & critical & critical & Pre critical & critical \\
\hline 2017 & & normal & critical & critical & Pre critical & critical \\
\hline
\end{tabular}

Table 5. The first option of calculation of annual cost cutting due to energy-conservative measures at Enterprise 1 (developed by the author).

\begin{tabular}{cccccccc}
\hline $\begin{array}{c}\text { Energy conservation measures object: } \\
\text { Workshop No.1 }\end{array}$ & 1 & 2 & 3 & 4 & 5 & 6 \\
\hline
\end{tabular}

Tax tariffs and rates

\begin{tabular}{|c|c|c|c|c|c|c|}
\hline Natural gas cost, roub $/ \mathrm{m}^{3}$ & 4,68741 & 4,6874 & 4,68741 & 4,68741 & 4,68741 & 4,68741 \\
\hline Electric power tariff, roub $/ \mathrm{kW} \times \mathrm{h}$ & 1,2146 & 1,2146 & 1,2146 & 1,2146 & 1,2146 & 1,2146 \\
\hline Nitrogen oxide emission tax rate, roub/t & 1434,71 & 1434,7 & 1434,71 & 1434,71 & 1434,71 & 1434,71 \\
\hline Carbonic oxide emission tax rate, roub/t & 54,05 & 54,05 & 54,05 & 54,05 & 54,05 & 54,05 \\
\hline Carbon dioxide emission tax rate, roub/t & 0,24 & 0,24 & 0,24 & 0,24 & 0,24 & 0,24 \\
\hline \multicolumn{7}{|c|}{ Decrease in consumption of energy resources of } \\
\hline natural gas, $\mathrm{m}^{3}$ & 32400 & 3240 & 0 & 0 & 0 & 0 \\
\hline electric power, $\mathrm{kW} \times \mathrm{h}$ & 0 & 0 & 0 & 0 & 0 & 15750 \\
\hline
\end{tabular}




\begin{tabular}{lcccccc}
\hline Emissions reduction $\mathrm{NO}_{\mathrm{x}}, \mathrm{t}$ & 0,102384 & 0,0102 & 0 & 0 & 0 & 0 \\
Administration building measures & 1 & 2 & 3 & 4 & 5 & 6 \\
Emissions reduction $\mathrm{CO}, \mathrm{t}$ & 0,014567 & 0,0015 & 0 & 0 & 0 & 0 \\
Emissions reduction $\mathrm{CO}_{2}, \mathrm{t}$ & 50,34493 & 5,0345 & 0 & 0 & 0 & 0 \\
\hline
\end{tabular}

Cost cutting due to given measure

$\begin{aligned} & \text { Due to decrease in energy consumption, } \\ & \text { roub }\end{aligned}$
$\begin{aligned} & \text { Due to decrease in gas consumption, } \\ & \text { roub }\end{aligned}$
$\begin{aligned} & \text { Due to decrease of ecological pays, roub } \\ & \begin{array}{l}\text { General saving from measure } \\ \text { introduction, thous. roub }\end{array}\end{aligned}$

Table 6. The second option of calculation of annual cost cutting due to energy-conservative measures at Enterprise 1.

\begin{tabular}{|c|c|c|c|c|}
\hline Energy saving measures for Workshop No.1 & 7 & 8 & 9 & 10 \\
\hline \multicolumn{5}{|c|}{ Tax tariffs and rates } \\
\hline Natural gas cost, roub $/ \mathrm{m}^{3}$ & 4,68741 & 4,68741 & 4,68741 & 4,68741 \\
\hline Electric power tariff, roub $/ \mathrm{kW} \times \mathrm{h}$ & 1,2146 & 1,2146 & 1,2146 & 1,2146 \\
\hline Nitrogen oxide emission tax rate, roub/t & 1434,71 & 1434,71 & 1434,71 & 1434,71 \\
\hline Carbonic oxide emission tax rate, roub/t & 54,05 & 54,05 & 54,05 & 54,05 \\
\hline Carbon dioxide emission tax rate, roub/t & 0,24 & 0,24 & 0,24 & 0,24 \\
\hline \multicolumn{5}{|c|}{ Decrease in consumption of energy resources of } \\
\hline natural gas, $\mathrm{m}^{3}$ & 0 & 0 & 226800 & 64800 \\
\hline electric power, $\mathrm{kW} \times \mathrm{h}$ & 5400 & 32400 & 0 & 0 \\
\hline \multicolumn{5}{|c|}{ Emission cuts } \\
\hline Emissions reduction $\mathrm{NO}_{\mathrm{x}}, \mathrm{t}$ & 0 & 0 & 0,716688 & 0,20477 \\
\hline Administration building measures & 0 & 0 & 0,101969 & 0,02913 \\
\hline Emissions reduction $\mathrm{CO}, \mathrm{t}$ & 0 & 0 & 352,4145 & 100,69 \\
\hline \multicolumn{5}{|c|}{ Cost cutting due to given measure } \\
\hline Due to decrease in energy consumption, roub & 6558,84 & 39353,04 & 0 & 0 \\
\hline Due to decrease in gas consumption, roub & 0 & 0 & 1063105 & 303744 \\
\hline Due to decrease of ecological pays, roub & 0 & 0 & 1118,33 & 319,523 \\
\hline General saving from measure introduction, thous. roub & 6,55884 & 39,35304 & 1064,223 & 304,064 \\
\hline
\end{tabular}

Table 7. The first option of summary table of calculation of annual saving from energy-conservative measures at Enterprise 1 and necessary investment resources for their implementation.

Energy $\quad$ Objects on which energy saving measures are planned 


\begin{tabular}{|c|c|c|c|c|c|c|c|c|c|c|c|c|c|c|}
\hline \multirow[t]{3}{*}{$\begin{array}{c}\text { conservati } \\
\text { on } \\
\text { measure }\end{array}$} & \multicolumn{2}{|c|}{$\begin{array}{c}\text { Administ } \\
\text { ration } \\
\text { building }\end{array}$} & \multicolumn{2}{|c|}{$\begin{array}{c}\text { Worksho } \\
\text { p } 1\end{array}$} & \multicolumn{2}{|c|}{$\begin{array}{c}\text { Worksho } \\
\text { p } 2\end{array}$} & \multicolumn{2}{|c|}{ Workshop 3} & \multicolumn{2}{|c|}{ Workshop 4} & \multicolumn{2}{|c|}{ Boiler-room } & \multicolumn{2}{|c|}{ Warehouse } \\
\hline & \multicolumn{14}{|c|}{$\begin{array}{c}\text { Investment capital } I \text {, thous. roubles and general saving from } R \text { measure implementation, thous. } \\
\text { roubles }\end{array}$} \\
\hline & $\mathbf{I}_{1}$ & $\mathbf{R}_{1}$ & $\mathbf{I}_{2}$ & $\mathbf{R}_{2}$ & $\mathbf{I}_{3}$ & $\mathbf{R}_{\mathbf{3}}$ & $\mathbf{I}_{\mathbf{4}}$ & $\mathbf{R}_{4}$ & $\mathbf{I}_{5}$ & $\mathbf{R}_{5}$ & $\mathbf{I}_{5}$ & $\mathbf{R}_{5}$ & $\mathbf{I}_{5}$ & $\mathbf{R}_{5}$ \\
\hline $\begin{array}{l}\text { Measure } \\
\text { No.1 }\end{array}$ & $\begin{array}{l}207 \\
331\end{array}$ & $\begin{array}{l}63 \\
347\end{array}$ & $\begin{array}{l}406, \\
277\end{array}$ & $\begin{array}{l}152 \\
, 03\end{array}$ & $\begin{array}{l}485, \\
903\end{array}$ & $\begin{array}{l}190 \\
, 04\end{array}$ & $\begin{array}{l}614, \\
6625\end{array}$ & $\begin{array}{l}253, \\
4\end{array}$ & $\begin{array}{l}1103 \\
, 579\end{array}$ & $\begin{array}{l}506, \\
8\end{array}$ & $\begin{array}{l}107, \\
8823\end{array}$ & $\begin{array}{l}25,3 \\
4\end{array}$ & $\begin{array}{l}351,7 \\
8933\end{array}$ & $\begin{array}{l}126,6 \\
9\end{array}$ \\
\hline $\begin{array}{l}\text { Measure } \\
\text { No. } 2\end{array}$ & 9 & $\begin{array}{l}633 \\
47\end{array}$ & 24 & $\begin{array}{l}15, \\
203\end{array}$ & 33 & $\begin{array}{l}19 \\
004\end{array}$ & 56 & $\begin{array}{l}25,3 \\
3864\end{array}$ & 70 & $\begin{array}{l}50,6 \\
7728\end{array}$ & $5: 4$ & $\begin{array}{l}7,60 \\
1592\end{array}$ & 24 & $\begin{array}{l}12,66 \\
932\end{array}$ \\
\hline $\begin{array}{l}\text { Measure } \\
\text { No.3 }\end{array}$ & $\mathrm{M}$ & 0 & 50,4 & 0 & 40,5 & $\begin{array}{l}114 \\
, 02\end{array}$ & 36 & $\begin{array}{l}101, \\
3546\end{array}$ & 93,6 & $\begin{array}{l}304, \\
0637\end{array}$ & 6,12 & $\begin{array}{l}15,2 \\
0318\end{array}$ & 11,4 & $\begin{array}{l}25,33 \\
8641\end{array}$ \\
\hline $\begin{array}{l}\text { Measure } \\
\text { No. } 4\end{array}$ & & 0 & & 0 & & 0 & & 0 & & 0 & 620 & $\begin{array}{l}3287 \\
, 942\end{array}$ & & 0 \\
\hline $\begin{array}{l}\text { Measure } \\
\text { No. } 5\end{array}$ & & 0 & & 0 & & 0 & & 0 & & 0 & 230 & $\begin{array}{l}4603 \\
, 119\end{array}$ & & 0 \\
\hline $\begin{array}{l}\text { Measure } \\
\text { No.6 }\end{array}$ & 0 & 0 & 8,75 & $\begin{array}{l}19, \\
13\end{array}$ & 9 & $\begin{array}{l}15 \\
304\end{array}$ & 6,75 & $\begin{array}{l}11,4 \\
7797\end{array}$ & 2,3 & $\begin{array}{l}7,65 \\
198\end{array}$ & 1,95 & $\begin{array}{l}2,29 \\
5594\end{array}$ & 1,56 & $\begin{array}{l}1,530 \\
396\end{array}$ \\
\hline $\begin{array}{l}\text { Measure } \\
\text { No.7 }\end{array}$ & $\mathrm{H}$ & $\begin{array}{l}173 \\
29\end{array}$ & 7,2 & $\begin{array}{l}6,5 \\
588\end{array}$ & 9 & $\begin{array}{l}8,1 \\
986\end{array}$ & 14 & $\begin{array}{l}10,9 \\
314\end{array}$ & 20 & $\begin{array}{l}21,8 \\
628\end{array}$ & $1: 4$ & $\begin{array}{l}1,09 \\
314\end{array}$ & 10 & $\begin{array}{l}5,465 \\
7\end{array}$ \\
\hline $\begin{array}{l}\text { Measure } \\
\text { No. } 8\end{array}$ & & 0 & 54 & $\begin{array}{l}39, \\
353\end{array}$ & & 0 & & 0 & & 0 & & 0 & & 0 \\
\hline $\begin{array}{l}\text { Measure } \\
\text { No. } 9\end{array}$ & 200 & $\begin{array}{l}443 \\
, 43\end{array}$ & 540 & $\begin{array}{l}106 \\
4,2\end{array}$ & $\begin{array}{l}562 \\
5\end{array}$ & $\begin{array}{l}133 \\
0,3\end{array}$ & 560 & $\begin{array}{l}1773 \\
, 705\end{array}$ & 1500 & $\begin{array}{l}3547 \\
, 41\end{array}$ & 55 & $\begin{array}{l}177 \\
3705\end{array}$ & 175 & $\begin{array}{l}886,8 \\
5243\end{array}$ \\
\hline $\begin{array}{l}\text { Measure } \\
\text { No. } 10\end{array}$ & 25 & $\begin{array}{l}126 \\
, 69\end{array}$ & 56 & $\begin{array}{l}304 \\
, 06\end{array}$ & 64 & $\begin{array}{l}380 \\
, 08\end{array}$ & 37 & $\begin{array}{l}506, \\
7728\end{array}$ & 54 & $\begin{array}{l}1013 \\
, 546\end{array}$ & 28 & $\begin{array}{l}50,6 \\
7728\end{array}$ & 67 & $\begin{array}{l}253,3 \\
8641\end{array}$ \\
\hline
\end{tabular}

Table 8. Calculation of complete economic effect of energy saving measure "Replacement of equipment engines to less powerful ones" of Enterprise 1.

\begin{tabular}{|c|c|c|c|c|c|c|c|c|c|c|c|}
\hline \multirow{2}{*}{$\begin{array}{c}\begin{array}{c}\text { Calculation of } \\
\text { complete } \\
\text { economic effect }\end{array} \\
\text { Years }\end{array}$} & \multicolumn{4}{|c|}{ Short-term period } & \multicolumn{3}{|c|}{ Average term } & \multicolumn{4}{|c|}{ Long-term period } \\
\hline & $\mathbf{0}$ & 1 & 2 & 3 & 4 & 5 & 6 & 7 & 8 & 9 & 10 \\
\hline $\begin{array}{l}\text { Investment } \\
\text { expenditures }\end{array}$ & $\begin{array}{c}8750,0 \\
0\end{array}$ & & & & & & & & & & \\
\hline $\begin{array}{l}\text { Net economic } \\
\text { saving }\end{array}$ & & $\begin{array}{c}1913 \\
0\end{array}$ & $\begin{array}{c}1913 \\
0\end{array}$ & $\begin{array}{c}1913 \\
0\end{array}$ & $\begin{array}{c}1913 \\
0\end{array}$ & 19130 & 19130 & 19130 & 19130 & 19130 & 19130 \\
\hline $\begin{array}{l}\text { Reinvested } \\
\text { earnings share } \\
\text { (RE) }\end{array}$ & & 0,30 & 0,30 & 0,30 & 0,30 & 0,30 & 0,30 & 0,30 & 0,30 & 0,30 & 0,30 \\
\hline $\begin{array}{l}\text { Profit after } \\
\text { reinvestment }\end{array}$ & & $\begin{array}{c}1339 \\
1\end{array}$ & $\begin{array}{c}1339 \\
1\end{array}$ & $\begin{array}{c}1339 \\
1\end{array}$ & $\begin{array}{c}1339 \\
1\end{array}$ & 13391 & 13391 & 13391 & 13391 & 13391 & 13391 \\
\hline Average \% RE & & 1,15 & 1,15 & 1,15 & 1,15 & 1,15 & 1,15 & 1,15 & 1,15 & 1,15 & 1,15 \\
\hline
\end{tabular}




\begin{tabular}{|c|c|c|c|c|c|c|c|c|c|c|c|}
\hline $\begin{array}{l}\text { Profit } \quad \text { from } \\
\text { previous years }\end{array}$ & & & & & & & & & & & \\
\hline $1^{\text {st }}$ year & & & 6600 & 7590 & 8728 & 10038 & 11543 & 13275 & 15266 & 17556 & 20189 \\
\hline $2^{\text {nd }}$ year & & & & 6600 & 7590 & 8728 & 10038 & 11543 & 13275 & 15266 & 17556 \\
\hline $3^{\text {rd }}$ year & & & & & 6600 & 7590 & 8728 & 10038 & 11543 & 13275 & 15266 \\
\hline $4^{\text {th }}$ year & & & & & & 6600 & 7590 & 8728 & 10038 & 11543 & 13275 \\
\hline $5^{\text {th }}$ year & & & & & & & 6600 & 7590 & 8728 & 10038 & 11543 \\
\hline $6^{\text {th }}$ year & & & & & & & & 6600 & 7590 & 8728 & 10038 \\
\hline $7^{\text {th }}$ year & & & & & & & & & 6600 & 7590 & 8728 \\
\hline $8^{\text {th }}$ year & & & & & & & & & & 6600 & 7590 \\
\hline $9^{\text {th }}$ year & & & & & & & & & & & 6600 \\
\hline Total income yy & & 0 & 6600 & $\begin{array}{c}1419 \\
0\end{array}$ & $\begin{array}{c}2291 \\
8\end{array}$ & 32956 & 44499 & 57773 & 73039 & 90595 & $\begin{array}{c}11078 \\
4\end{array}$ \\
\hline Project cost & & 8000 & 7667 & 7334 & 7001 & 6668 & 6335 & 6002 & 5669 & 5336 & 5003 \\
\hline $\begin{array}{l}\text { Payments } \\
\text { investor }\end{array}$ & & $\begin{array}{c}- \\
1006\end{array}$ & $\begin{array}{c}- \\
1006\end{array}$ & $\begin{array}{c}- \\
1006\end{array}$ & -1006 & -1006 & -1006 & -1006 & -1006 & -1006 & -1006 \\
\hline $\begin{array}{l}\text { Disbursement of } \\
\text { loan }\end{array}$ & & & & & & & & & & & -4375 \\
\hline $\begin{array}{l}\text { CEE exclusively } \\
\text { of Project cost }\end{array}$ & -8750 & 3635 & $\begin{array}{c}2262 \\
0\end{array}$ & $\begin{array}{c}4919 \\
5\end{array}$ & $\begin{array}{c}8449 \\
8\end{array}$ & $\begin{array}{c}12983 \\
8\end{array}$ & $\begin{array}{c}18672 \\
2\end{array}$ & $\begin{array}{c}25688 \\
0\end{array}$ & $\begin{array}{c}34230 \\
4\end{array}$ & $\begin{array}{c}44528 \\
4\end{array}$ & $\begin{array}{c}56407 \\
8\end{array}$ \\
\hline $\begin{array}{l}\text { CEE including } \\
\text { Project cost }\end{array}$ & -8750 & $\begin{array}{c}1163 \\
5\end{array}$ & $\begin{array}{c}3028 \\
7\end{array}$ & $\begin{array}{c}5652 \\
9\end{array}$ & $\begin{array}{c}9149 \\
9\end{array}$ & $\begin{array}{c}13650 \\
6\end{array}$ & $\begin{array}{c}19305 \\
7\end{array}$ & $\begin{array}{c}26288 \\
2\end{array}$ & $\begin{array}{c}34797 \\
3\end{array}$ & $\begin{array}{c}45062 \\
0\end{array}$ & $\begin{array}{c}56908 \\
1\end{array}$ \\
\hline
\end{tabular}

Table 9. The second variant of calculation of complete economic effect of energy saving measure "Increasing envelope building thermal insulation resistance" Enterprise 1" (developed by the author).

\begin{tabular}{|c|c|c|c|c|c|c|c|c|c|c|c|}
\hline Calculation of & \multicolumn{4}{|c|}{ Short-term period } & \multicolumn{3}{|c|}{ Average term } & \multicolumn{4}{|c|}{ Long-term period } \\
\hline Years & $\mathbf{0}$ & 1 & 2 & 3 & 4 & 5 & 6 & 7 & 8 & 9 & 10 \\
\hline $\begin{array}{l}\text { Investment } \\
\text { expenditures }\end{array}$ & $\begin{array}{l}207331 \\
\quad 00\end{array}$ & & & & & & & & & & \\
\hline $\begin{array}{l}\text { Net economic } \\
\text { saving }\end{array}$ & & $\begin{array}{c}6334 \\
7\end{array}$ & $\begin{array}{c}6334 \\
7\end{array}$ & $\begin{array}{c}6334 \\
7\end{array}$ & $\begin{array}{c}6334 \\
7\end{array}$ & 63347 & $\begin{array}{c}6334 \\
7\end{array}$ & $\begin{array}{c}6334 \\
7\end{array}$ & $\begin{array}{c}6334 \\
7\end{array}$ & 63347 & 63347 \\
\hline $\begin{array}{l}\text { Reinvested } \\
\text { earnings share } \\
\text { (RE) }\end{array}$ & & 0,30 & 0,30 & 0,30 & 0,30 & 0,30 & 0,30 & 0,30 & 0,30 & 0,30 & 0,30 \\
\hline $\begin{array}{l}\text { Profit after } \\
\text { reinvestment }\end{array}$ & & $\begin{array}{c}4434 \\
3\end{array}$ & $\begin{array}{c}4434 \\
3\end{array}$ & $\begin{array}{c}4434 \\
3\end{array}$ & $\begin{array}{c}4434 \\
3\end{array}$ & 44343 & $\begin{array}{c}4434 \\
3\end{array}$ & $\begin{array}{c}4434 \\
3\end{array}$ & $\begin{array}{c}4434 \\
3\end{array}$ & 44343 & 44343 \\
\hline Average \% RE & & 1,15 & 1,15 & 1,15 & 1,15 & 1,15 & 1,15 & 1,15 & 1,15 & 1,15 & 1,15 \\
\hline \multicolumn{12}{|l|}{$\begin{array}{l}\text { Profit from } \\
\text { previous years }\end{array}$} \\
\hline $1^{\text {st }}$ year & & & 2185 & 2513 & 2890 & 33238 & 3822 & 4395 & 5055 & 58134 & 66854 \\
\hline
\end{tabular}




\begin{tabular}{|c|c|c|c|c|c|c|c|c|c|c|c|}
\hline & & & 5 & 3 & 3 & & 4 & 8 & 1 & & \\
\hline $2^{\text {nd }}$ year & & & & $\begin{array}{c}2185 \\
5\end{array}$ & $\begin{array}{c}2513 \\
3\end{array}$ & 28903 & $\begin{array}{c}3323 \\
8\end{array}$ & $\begin{array}{c}3822 \\
4\end{array}$ & $\begin{array}{c}4395 \\
8\end{array}$ & 50551 & 58134 \\
\hline $3^{\text {rd }}$ year & & & & & $\begin{array}{c}2185 \\
5\end{array}$ & 25133 & $\begin{array}{c}2890 \\
3\end{array}$ & $\begin{array}{c}3323 \\
8\end{array}$ & $\begin{array}{c}3822 \\
4\end{array}$ & 43958 & 50551 \\
\hline $4^{\text {th }}$ year & & & & & & 21855 & $\begin{array}{c}2513 \\
3\end{array}$ & $\begin{array}{c}2890 \\
3\end{array}$ & $\begin{array}{c}3323 \\
8\end{array}$ & 38224 & 43958 \\
\hline $5^{\text {th }}$ year & & & & & & & $\begin{array}{c}2185 \\
5\end{array}$ & $\begin{array}{c}2513 \\
3\end{array}$ & $\begin{array}{c}2890 \\
3\end{array}$ & 33238 & 38224 \\
\hline $6^{\text {th }}$ year & & & & & & & & $\begin{array}{c}2185 \\
5\end{array}$ & $\begin{array}{c}2513 \\
3\end{array}$ & 28903 & 33238 \\
\hline $7^{\text {th }}$ year & & & & & & & & & $\begin{array}{c}2185 \\
5\end{array}$ & 25133 & 28903 \\
\hline $8^{\text {th }}$ year & & & & & & & & & & 21855 & 25133 \\
\hline $9^{\text {th }}$ year & & & & & & & & & & & 21855 \\
\hline $\begin{array}{l}\text { Total income } \\
\text { yy }\end{array}$ & & 0 & $\begin{array}{c}2185 \\
5\end{array}$ & $\begin{array}{c}4698 \\
8\end{array}$ & $\begin{array}{c}7589 \\
0\end{array}$ & $\begin{array}{c}10912 \\
9\end{array}$ & $\begin{array}{c}1473 \\
53\end{array}$ & $\begin{array}{c}1913 \\
10\end{array}$ & $\begin{array}{c}2418 \\
62\end{array}$ & $\begin{array}{c}29999 \\
6\end{array}$ & $\begin{array}{c}36685 \\
0\end{array}$ \\
\hline Project cost & & 0 & 0 & 0 & 0 & 0 & 0 & 0 & 0 & 0 & 0 \\
\hline $\begin{array}{l}\text { Payments to } \\
\text { investor }\end{array}$ & & $\begin{array}{c}- \\
1897 \\
5\end{array}$ & $\begin{array}{c}- \\
1897 \\
5\end{array}$ & $\begin{array}{c}- \\
1897 \\
5\end{array}$ & $\begin{array}{c}- \\
1897 \\
5\end{array}$ & $\begin{array}{c}- \\
18975\end{array}$ & $\begin{array}{c}- \\
1897 \\
5\end{array}$ & $\begin{array}{c}- \\
1897 \\
5\end{array}$ & $\begin{array}{c}- \\
1897 \\
5\end{array}$ & -18975 & -18975 \\
\hline $\begin{array}{l}\text { Disbursement } \\
\text { of loan }\end{array}$ & & & & & & & & & & & $\begin{array}{c}- \\
10366 \\
6\end{array}$ \\
\hline $\begin{array}{l}\text { CEE } \\
\text { exclusively of } \\
\text { Project cost }\end{array}$ & -207331 & $\begin{array}{c}- \\
1819 \\
63\end{array}$ & $\begin{array}{c}- \\
1347 \\
40\end{array}$ & $\begin{array}{c}- \\
6238 \\
5\end{array}$ & $\begin{array}{c}3887 \\
3\end{array}$ & $\begin{array}{c}17337 \\
0\end{array}$ & $\begin{array}{c}3460 \\
91\end{array}$ & $\begin{array}{c}5627 \\
69\end{array}$ & $\begin{array}{c}8299 \\
99\end{array}$ & $\begin{array}{c}11553 \\
62\end{array}$ & $\begin{array}{c}14439 \\
14\end{array}$ \\
\hline $\begin{array}{l}\text { CEE including } \\
\text { Project cost }\end{array}$ & -207331 & $\begin{array}{l}- \\
1819 \\
63\end{array}$ & $\begin{array}{l}- \\
1347 \\
40\end{array}$ & $\begin{array}{l}- \\
6238 \\
5\end{array}$ & $\begin{array}{l}3887 \\
3\end{array}$ & $\begin{array}{l}17337 \\
0\end{array}$ & $\begin{array}{l}3460 \\
91\end{array}$ & $\begin{array}{l}5627 \\
69\end{array}$ & $\begin{array}{l}8299 \\
99\end{array}$ & $\begin{array}{l}11553 \\
62\end{array}$ & $\begin{array}{l}14439 \\
14\end{array}$ \\
\hline
\end{tabular}

Table 10. The first option of calculation of the components of the indicator of investment attractiveness of energy saving measure at enterprise (developed by the author).

\begin{tabular}{|c|c|c|c|}
\hline Variable designation & $\begin{array}{c}\text { Expert } \\
\text { evaluation }\end{array}$ & Value of variable & $\begin{array}{c}\text { Expert } \\
\text { evaluation }\end{array}$ \\
\hline $\begin{array}{l}\mathrm{x}_{1}-\mathrm{LZ} \text { "complete economic } \\
\text { effect" (Rj) }\end{array}$ & 9 & $\begin{array}{l}\mathrm{y}_{5}-\mathrm{LZ} \text { "technical superiority of the } \\
\text { properties of equipment or material over } \\
\text { analogous projects" }\end{array}$ & $0,776^{*}$ \\
\hline $\mathrm{x}_{2}-\mathrm{LZ}$ "pay-off period" & 10 & $b_{1}-\mathrm{LZ}$ "by output performance, KPI" & 1 \\
\hline $\begin{array}{l}\mathrm{x}_{3}-\mathrm{LZ} \text { "coefficient of project's } \\
\text { financial autonomy" }\end{array}$ & 0,3 & $\begin{array}{l}\mathrm{b}_{2}-\mathrm{LZ} \text { "by weight and geometrical } \\
\text { properties" }\end{array}$ & 1 \\
\hline $\mathrm{x}_{4}-\mathrm{LZ}$ "project life term" & 25 & $\begin{array}{l}\mathrm{z}_{1}-\mathrm{LZ} \text { "technical complexity of } \\
\text { exploitation process" }\end{array}$ & 80 \\
\hline $\mathrm{x}_{5}-\mathrm{LZ}$ “project riskiness" & 10 & $\mathrm{z}_{2}-\mathrm{LZ}$ "qualification level of the staff" & 2 \\
\hline $\begin{array}{l}y_{1}-\text { LZ "correspondence of } \\
\text { current production to modern }\end{array}$ & 4,5 & $\begin{array}{l}\mathrm{z}_{3}-\mathrm{LZ} \text { "the level of manufacturer's } \\
\text { technical support" }\end{array}$ & 1 \\
\hline
\end{tabular}




\begin{tabular}{|c|c|c|c|}
\hline \multicolumn{4}{|l|}{ regulations" } \\
\hline $\begin{array}{l}\mathrm{y}_{2}-\mathrm{LZ} \text { "project environmental } \\
\text { friendliness" }\end{array}$ & 1 & $\begin{array}{l}\mathrm{z}_{4}-\mathrm{LZ} \text { "the degree of abatement of } \\
\text { emissions in environment" }\end{array}$ & 10 \\
\hline $\begin{array}{l}\mathrm{y}_{3}-\mathrm{LZ} \text { "need for enterprise } \\
\text { modernization" }\end{array}$ & $4,18 *$ & $\begin{array}{l}\mathrm{z}_{5}-\mathrm{LZ} \text { "equipment and materials } \\
\text { operating conditions" }\end{array}$ & $1,82 *$ \\
\hline $\mathrm{a}_{1}-\mathrm{LZ}$ equipment & 5 & $\mathrm{~d}_{1}-\mathrm{LZ}$ "equipment” & 1 \\
\hline $\mathrm{a}_{2}-\mathrm{LZ}$ "buildings and facilities" & 4 & $\mathrm{~d}_{2}-\mathrm{LZ}$ "materials" & 2 \\
\hline $\begin{array}{l}\mathrm{y}_{4}-\mathrm{LZ} \text { "degree of decreasing } \\
\text { products' energy output" }\end{array}$ & 10 & * designated calculated values of LZ & \\
\hline
\end{tabular}

Table 11. The second option of calculation of the components of the indicator of investment attractiveness of energy saving measure at enterprise (parameter L value).

\begin{tabular}{|c|c|c|c|c|}
\hline Parameter & $\begin{array}{l}\text { Variable designation and } \\
\text { name }\end{array}$ & Universal set & $\begin{array}{l}\text { Parameter } \\
\text { value }\end{array}$ & $\begin{array}{l}\text { Parameter } \\
\text { value }\end{array}$ \\
\hline \multirow[t]{3}{*}{$\begin{array}{l}\text { Investment } \\
\text { index (L) }\end{array}$} & Economic factor $(\mathrm{X})$ & $\begin{array}{c}U(X)=\{0 \ldots 1\} \\
(\text { scores })\end{array}$ & 0,746 & $L=0,5072$ \\
\hline & Technical factors (Y) & $\begin{array}{c}U(Y)=\{0 \ldots 1\} \\
(\text { scores })\end{array}$ & 0,263 & \\
\hline & Exploitation factors (Z) & $\begin{array}{c}U(Z)=\{0 \ldots 1\} \\
(\text { scores })\end{array}$ & 0,236 & \\
\hline
\end{tabular}

managers' failure to evaluate new organizational and legal problems:

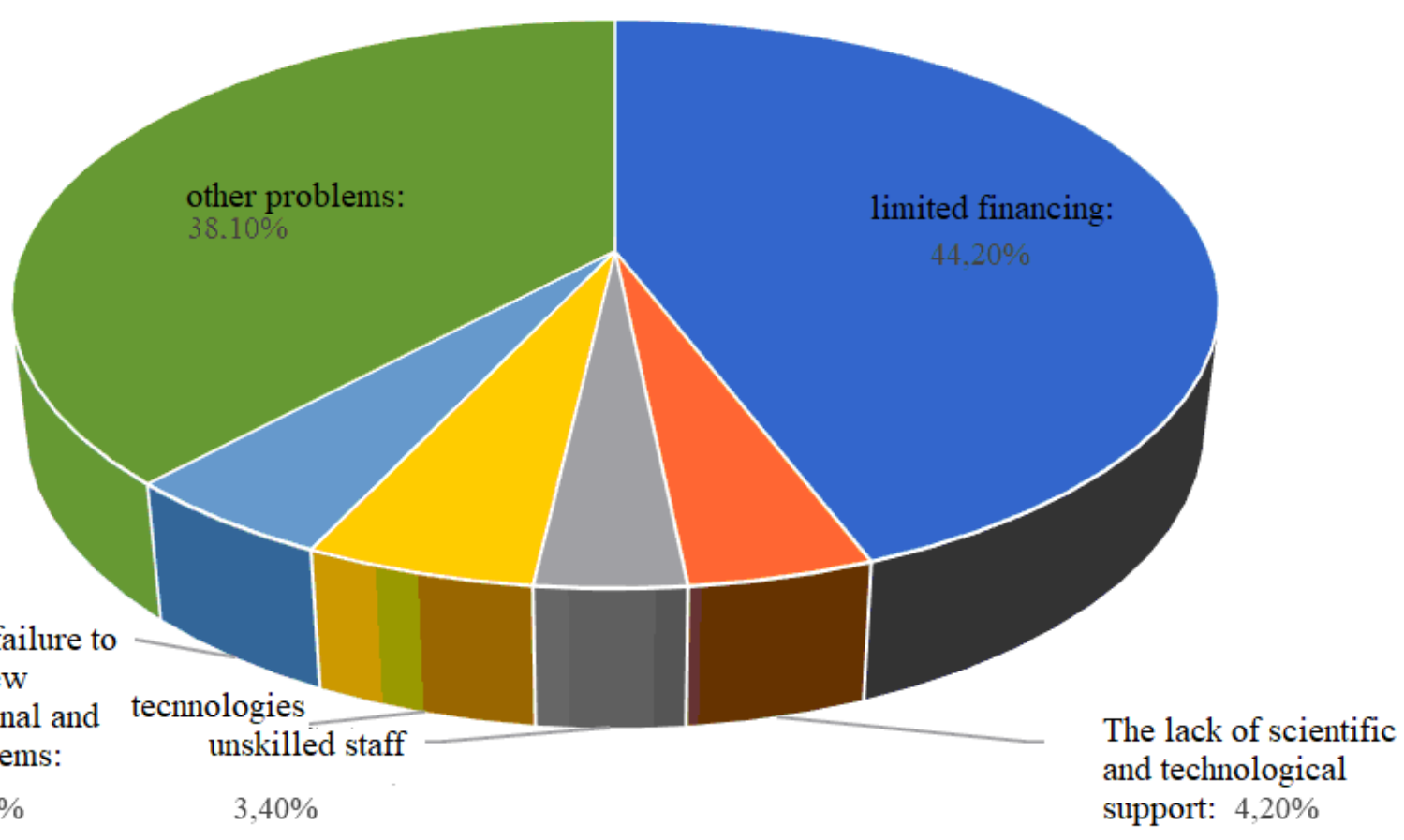


Figure 1. Distribution of factors preventing the introduction of advanced technologies, in $\%$ from the total number of enterprises (compiled by the author).

the number of enterprises introducing innovations - including energy-conserving ones
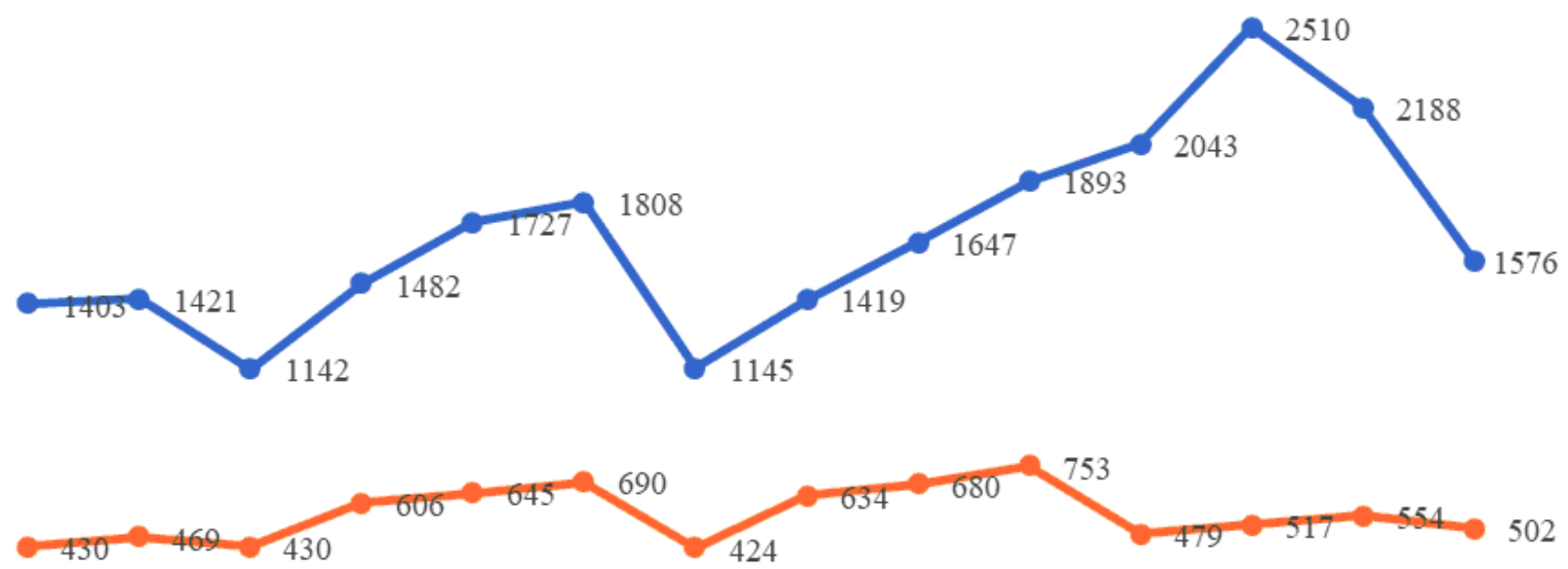

$\begin{array}{llllllllllllll}2004 & 2005 & 2006 & 2007 & 2008 & 2009 & 2010 & 2011 & 2012 & 2013 & 2014 & 2015 & 2016 & 2017\end{array}$

Figure 2. Dynamics of introduction of innovations at production enterprises [2]. 


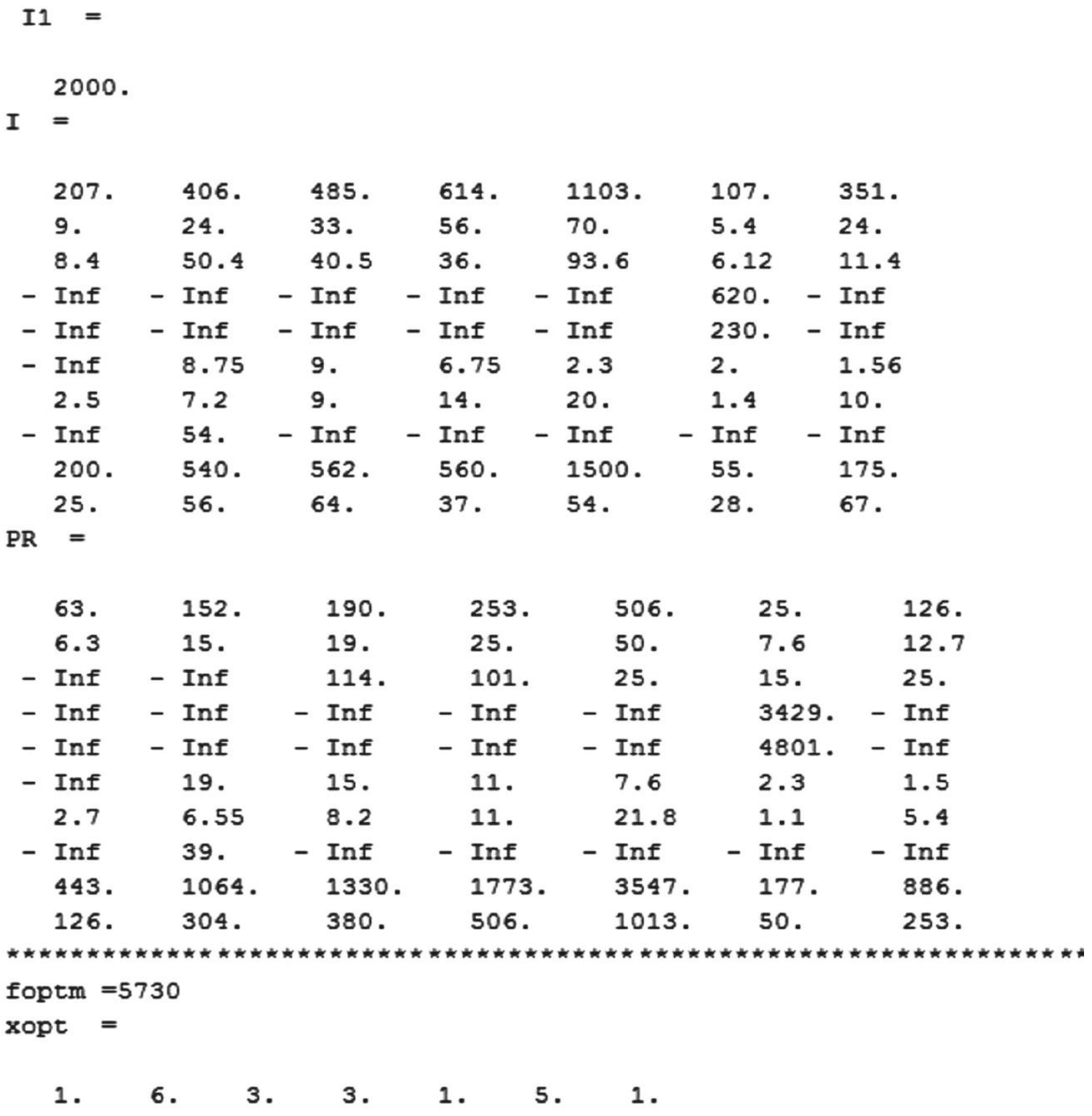

Figure 3. Results of calculation of the first stage of modeling of the option of priority measures of energy conservation for enterprise. 


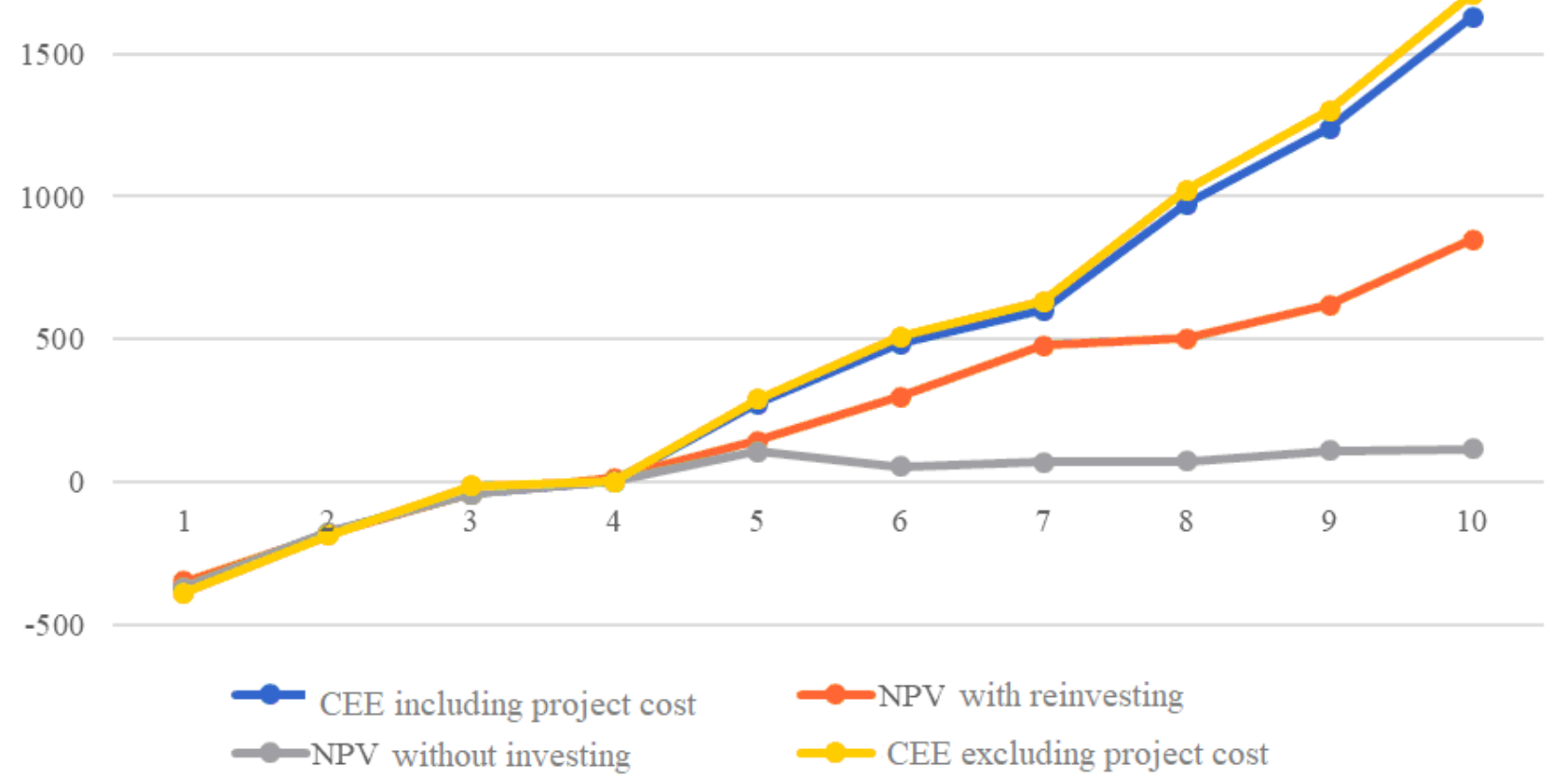

Figure 4. Graphic interpretation of results of calculation of CEE and NPV at investing in energy saving measure with the use of different methods (at project zero cost) (developed by the author).

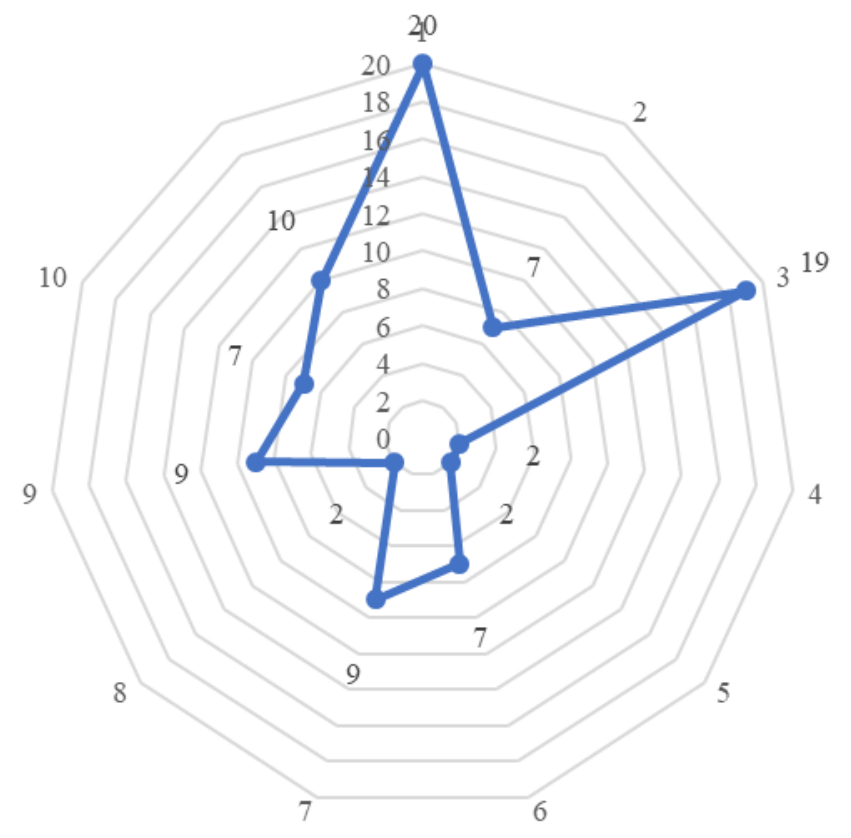

Figure 5. Priority measures of energy saving, which are recommended to be introduced at the units of production enterprises based on the results of economic energy inspection 